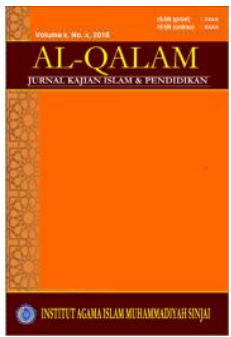

AL-QALAM

Jurnal Kajian Islam \& Pendidikan

Volume 9, No. 1, 2017

ISSN (print) : 1858-4152

ISSN (online) : xxxx-xxxx

Homepage : http://journal.iaimsinjai.ac.id/index.php/al-qalam

\title{
PENGEMBANGAN MEDIA ANIMASI PEMBELAJARAN BAHASA ARAB KELAS VI MIN ALEHANUAE KAB. SINJAI
}

\author{
Oleh : Takdir ${ }^{1}$
}

$* * *$

\begin{abstract}
Abstrak
Diperlukan variasi media dalam mempelajari keterampilan berbahasa untuk meningkatkan minat belajar siswa, terutama siswa pada usia MI/SD. Dengan adanya media yang menarik, maka siswa akan lebih bersemangat dalam belajar. Tujuan penelitian ini adalah (1) menghasilkan dan mendeskripsikan produk media animasi pembelajaran bahasa Arab kelas VI MI, (2) mendeskripsikan kelayakan produk sebagai media pembelajaran bahasa arab kelas VI MI, dan (3) mendeskripsikan model penggunaan produk dalam pembelajaran kelas VI MI. Penelitian ini menggunakan rancangan penelitian pengembangan. Model pengembangan yang digunakan pada penelitian ini mengacu pada model pengembangan Research and Development $(R \& D)$ Borg and Gall yang telah dimodifikasi Sugiyono. Untuk menyingkat waktu penelitian, maka peneliti menyederhanakan model Research and Development Sugiyono menjadi beberapa langkah: (1) analisis potensi dan masalah, (2) mendesain produk, (3) mengumpulkan materi, (4) membuat produk awal, (5) melakukan uji ahli, (6) merevisi produk, dan (7) melakukan uji lapangan. Data dalam penelitian ini berupa data kuantitatif dan kualitatif. Data kuantitatif diperoleh dari hasil angket untuk ahli media, ahli materi, dan subjek penelitian. Instrumen yang digunakan dalam pengumpulan data pengembangan media pembelajaran ini adalah instrumen berbentuk angket terstruktur dan penilaiannya menggunakan skala bertingkat. Sedangkan untuk mendapatkan data kualitatif pada tahap uji lapangan peneliti menggunakan metode observasi. Penelitian ini menghasilkan sebuah produk media $C D$ video animasi yang berisi media pembelajaran bahasa Arab tentang jam untuk kelas VI MI. Berdasarkan uji ahli, media ini termasuk dalam kategori layak dan berdasarkan uji lapangan, media ini termasuk dalam kategori sangat layak. Media ini bisa digunakan secara mandiri dan kelompok. Penggunaan secara mandiri dapat dilakukan di rumah setelah siswa mendapatkan materi tentang jam di sekolah, sedangkan penggunaan berkelompok dapat dilakukan dengan bantuan dan arahan dari guru.
\end{abstract}

Kata Kunci: Media Animasi, Bahasa Arab, MIN Alehanuae Kab. Sinjai

\section{PENDAHULUAN}

${ }^{1}$ Dosen Tetap Institut Agama Islam (IAI) Muhammadiyah Sinjai 


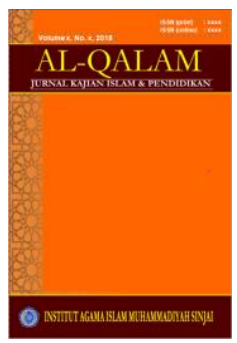

AL-QALAM

Jurnal Kajian Islam \& Pendidikan

Volume 9, No. 1, 2017

ISSN (print) : 1858-4152

ISSN (online) : xxxx-xxxx

Homepage : http://journal.iaimsinjai.ac.id/index.php/al-qalam

alah satu bahasa internasional yang digunakan secara luas dalam berbagai aspek adalah bahasa Arab. Dalam dunia internasional dan nasional, bahasa Arab digunakan untuk ilmu pengetahuan, pendidikan, bisnis, hiburan, dan agama. Karena itulah bahasa arab sangat penting untuk dikuasai. Menyadari kenyataan pentingnya bahasa Arab, maka pembelajaran bahasa Arab sedini mungkin sebaiknya diterapkan di sekolah-sekolah, terutama sekolah-sekolah Islam karena bahasa Arab juga memegang peranan penting dalam agama Islam. Namun pada kenyataanya, penerapan pelajaran bahasa Arab di sekolah-sekolah di Indonesia tidak berjalan efektif, tidak terkecuali di MIN Alehanuae Kab. Sinjai.

Berdasarkan hasil wawancara peneliti dengan guru bahasa Arab, siswasiswi kelas VI MIN Alehanuae Kab. Sinjai tidak bersemangat mengikuti pelajaran bahasa Arab. Salah satu penyebabnya adalah kurang efektifnya penggunaan media dalam pembelajaran di kelas karena keterbatasan media pembelajaran yang ada. Akibatnya, pembelajaran terasa menjemukan dan itu berimbas pada malasnya siswa untuk belajar bahasa Arab. Karena itulah dalam proses pembelajaran, seorang pengajar harus pintar memanfaatkan segala hal untuk membuat siswa tertarik dalam mempelajari bahasa Arab. Di sinilah peran media sangat penting. Kehadiran media dibutuhkan untuk mempermudah pemahaman siswa terhadap materi. Kesulitan materi yang sulit dapat disederhanakan dengan bantuan media. Melalui media keabstrakan bahan dapat dikonkretkan. Dengan demikian, siswa lebih mudah mencerna bahan daripada tanpa bantuan media.

Dengan media, pengajaran akan lebih menarik perhatian siswa sehingga dapat menumbuhkan motivasi belajar. Dengan media, bahan pengajaran akan lebih jelas maknanya sehingga dapat lebih dipahami oleh para siswa. Metode mengajar akan lebih bervariasi jika dipadu dengan media, terutama jika guru mengajar untuk setiap jam pelajaran. Selain itu dengan menggunakan media, siswa lebih banyak melakukan kegiatan belajar karena tidak hanya mendengarkan uraian guru, tetapi juga mengamati, melakukan, mendemonstrasikan, dll. 


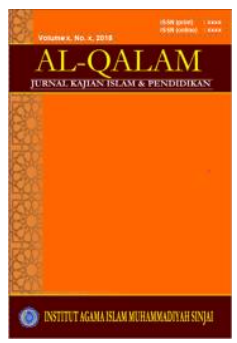

AL-QALAM

Jurnal Kajian Islam \& Pendidikan

Volume 9, No. 1, 2017

ISSN (print) : 1858-4152

ISSN (online) : xxxx-xxxx

Homepage : http://journal.iaimsinjai.ac.id/index.php/al-qalam

Asrori $^{2}$ menyebutkan bahwa media pembelajaran menurut indera dibagi menjadi 3 macam; (a) pembelajaran audio, yaitu pembelajaran dengan menggunakan indera pendengaran, seperti mendengarkan radio, program-program berita, dan lain sebagainya, (b) pembelajaran visual, yaitu pembelajaran menggunakan indera penglihatan. Media ini dibagi menjadi dua, yaitu dengan menggunakan alat penayangan seperti film dan tanpa menggunakan alat penayangan yang dibagi menjadi 3, yaitu: (1) benda dan kejadian nyata seperti pena, kacamata, dan aktifitas duduk, (2) benda dan kejadian buatan seperti miniatur dan peragaan, (3) gambar dan lukisan seperti gambar fotografi dan non fotografi, dan (c) pembelajaran audio visual, yaitu media pembelajaran yang digunakan untuk membantu guru dalam menyampaikan materi pelajaran dengan menggunakan indera pendengaran dan penglihatan secara bersamaan seperti film dan video, menonton televisi, dan drama.

Dalam perkembanganya, media pembelajaran bahasa asing sudah semakin maju. Media pembelajaran sekarang lebih banyak menggunakan media audio visual seiring dengan berkembangnya teknologi misalnya laptop, komputer tablet, ipad, dan handphone. Guru dan siswa sekarang lebih menyukai media pembelajaran yang praktis dan efisien, tidak terkecuali dalam pembelajaran bahasa Arab. Salah satu media pembelajaran bahasa yang praktis penggunaannya adalah media animasi. Menurut Wikipedia (2009) dalam Ramli ${ }^{3}$, animasi atau lebih akrab disebut dengan film animasi adalah film yang merupakan hasil dari pengolahan gambar tangan sehingga menjadi gambar yang bergerak. Media Animasi sangat cocok untuk pembelajaran bahasa Arab karena tampilannya yang menarik, penggunaannya yang mudah dan dapat digunakan berulang kali. Hal ini akan membuat siswa bersemangat dalam mempelajari bahasa Arab.

\footnotetext{
${ }^{2}$ Asrori, Imam. 1995. الوسائل المعبنات في تعليم العربيّة. Malang: (tanpa penerbit).

${ }^{3}$ Ramli, Kamrianti. 2011. Tanpa judul, (online), (http://kamriantiramli.wordpress.com/2011/02/28/pengaruh-penggunaan-media-animasi-sebagaistrategi-pembelajaran-aktif-pada-konsep-metabolisme-di-kelas-xii-man-negeri-2-sinjai/)diakses 13 Desember 2017.
} 


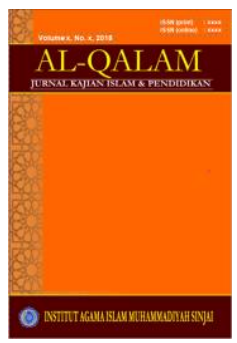

AL-QALAM

Jurnal Kajian Islam \& Pendidikan

Volume 9, No. 1, 2017

ISSN (print) : 1858-4152

ISSN (online) : xxxx-xxxx

Homepage : http://journal.iaimsinjai.ac.id/index.php/al-qalam

Berdasarkan uraian di atas, peneliti memilih media animasi sebagai objek pengembangan. Hal itu karena atas dasar pertimbangan bahwa tidak semua siswa memiliki komputer atau laptop. Media pembelajaran CD animasi bisa digunakan bersama-sama maupun digunakan perorangan. Media animasi juga dapat digunakan di VCD. Selain itu pengoprasian media animasi yang praktis akan mempermudah siswa dan guru dalam menggunakan media ini. Berdasarkan hal tersebut, maka penelitian pengembangan media animasi untuk pembelajaran bahasa arab kelas VI MI ini merupakan kebutuhan.

Untuk lokasi penelitian, dalam penelitian ini peneliti memilih MIN Alehanuae Kab. Sinjai sebagai tempat penelitian dikarenakan dari hasil observasi dan wawancara, diperoleh informasi bahwa guru bidang studi bahasa Arab kurang menggunakan media yang bervariasi karena minimnya media pembelajaran bahasa Arab di sekolah tersebut. Sehingga dapat ditarik kesimpulan bahwa pengembangan media animasi untuk pembelajaran bahasa Arab kelas VI MIN Alehanuae Kab. Sinjai diperlukan.

\section{METODE PENELITIAN}

Penelitian ini termasuk dalam kategori penelitian pengembangan karena penelitian ini menghasilkan sebuah produk animasi pembelajaran bahasa Arab yang sebelumnya belum ada, dengan kata lain hasil media pada penelitian ini merupakan hasil pengembangan karena menghasilkan sebuah produk baru.

Pemerolehan data dalam penelitian ini berupa data kuantitatif dan kualitatif. Berupa data kuantitatif karena data dinyatakan dalam bentuk angkaangka. Data tersebut merupakan hasil dari angket-angket, baik angket untuk ahli media, ahli materi, dan subjek penelitian. Berupa data kualitatif karena penelitian juga dilakukan melalui wawancara dan pengamatan kelas untuk mendapatkan deskripsi atau gambaran objek yang diteliti.

Instrumen yang digunakan dalam pengumpulan data pengembangan media pembelajaran ini adalah instrumen berbentuk angket terstruktur, yaitu angket 


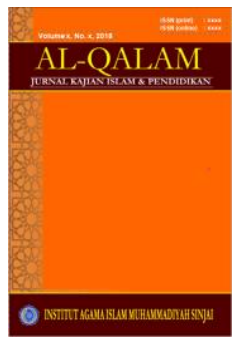

AL-QALAM

Jurnal Kajian Islam \& Pendidikan

Volume 9, No. 1, 2017

ISSN (print) : 1858-4152

ISSN (online) : xxxx-xxxx

Homepage : http://journal.iaimsinjai.ac.id/index.php/al-qalam

semua pertanyaan yang telah ditentukan jawabannya ${ }^{4}$ (Heriyanto,). Angket adalah sejumlah pertanyaan tertulis yang digunakan untuk memperoleh informasi dari responden ${ }^{5}$. Penggunaan instrumen tersebut bertujuan agar penilaian dari responden terarah dan tidak keluar dari produk. Penilaiannya menggunakan rating scale (skala bertingkat). Jawaban pada skala bertingkat merupakan interval. Tingkat penilaian dapat dilihat pada lampiran. Sedangkan untuk mendapatkan data kualitatif pada tahap uji lapangan peneliti menggunakan metode observasi.

Model prosedural merupakan model penelitian yang digunakan dalam penelitian ini. Model prosedural adalah model yang bersifat deskriptif, yaitu menggariskan langkah-langkah yang harus diikuti untuk menghasilkan produk ${ }^{6}$. Penelitian ini menghasilkan sebuah produk berupa video animasi yang berisi media pembelajaran bahasa Arab tentang jam untuk kelas VI MI.

Untuk mengembangkan suatu media pembelajaran diperlukan persiapan dan rancangan yang diteliti. Dalam pengembangan ini model yang akan dikembangkan adalah mengacu pada model pengembangan Research and Development (R\&D) Bog and Gall yang telah dimodifikasi Sugiyono yang terdiri dari langkah-langkah berikut: (1) potensi dan masalah, (2) pengumpulan data, (3) desain produk, (4) validasi desain, (5) revisi desain, (6) uji coba produk, (7) revisi produk, (8) uji coba pemakaian, (9) revisi produk, dan (10) produksi massal (Sugiyono dalam Suaidah, 2011). Untuk menyingkat waktu penelitian, maka peneliti menyederhanakan model Research and Development Sugiyono menjadi beberapa langkah sebagai berikut: (1) analisis potensi dan masalah, (2) mendesain produk, (3) mengumpulkan materi, (4) membuat produk awal, (5) melakukan uji ahli, (6) merevisi produk, dan (7) melakukan uji lapangan. Pustaka. 2006)

${ }^{4}$ M. Heriyanto, Albertus, dan B. Sandjaja,. Panduan Penelitian. (Jakarta: Prestasi

${ }^{5}$ Moh. Ainin, Metode Penelitian Bahasa Arab. (Surabaya. Hilal Pustaka 2010)

${ }^{6}$ Suaidah, Nisful Laily. Pengembangan Media Pembelajaran Berbasis Adobe Flash CS3 dalam Kemahiran Kalam untuk Siswa Kelas VII SMP Darul Qur'an Singosari Malang. (Skripsi tidak diterbitkan. Malang: Fakultas Sastra Universitas Negeri Malang. 2011). 


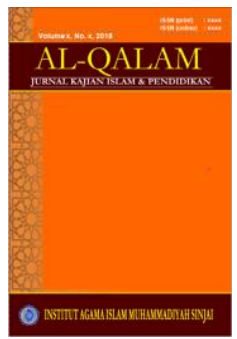

Volume 9, No. 1, 2017

ISSN (print) : 1858-4152

ISSN (online) : :xxx-xxxx

Homepage : http://journal.iaimsinjai.ac.id/index.php/al-qalam

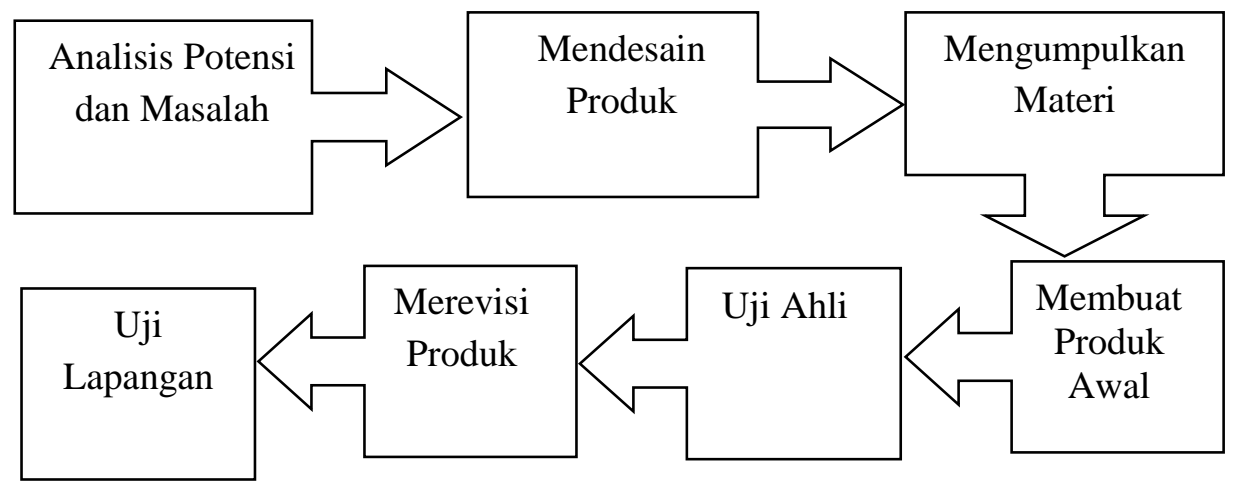

Bagan 3.1 Model pengembangan Research and Development (R\&D) Sugiyono yang telah disederhanakan peneliti

\section{HASIL DAN PEMBAHASAN}

Pada bagian ini disajikan hasil penelitian pengembangan media animasi untuk pembelajaran bahasa Arab siswa kelas VI MIN Alehanuae Kab. Sinjai Kedungkandang, Malang, yang meliputi (a) produk pengembangan media animasi pembelajaran bahasa Arab siswa kelas VI MIN Alehanuae Kab. Sinjai, kelayakan produk, dan (c) model penggunaan.

\section{A. Produk Pengembangan Media Animasi Pembelajaran Bahasa Arab Kelas VI MI}

Media animasi adalah media dengan rangkaian gambar yang disusun secara berurutan. Ketika rangkaian gambar tersebut ditampilkan dengan kecepatan yang memadai, rangkaian gambar tersebut akan terlihat bergerak. Biasanya 


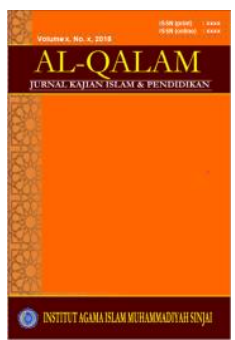

\section{AL-QALAM}

Jurnal Kajian Islam \& Pendidikan

Volume 9, No. 1, 2017

ISSN (print) : 1858-4152

ISSN (online) : xxxx-xxxx

Homepage : http://journal.iaimsinjai.ac.id/index.php/al-qalam

kecepatan animasi diukur dalam fps (frame per second), yaitu banyaknya gambar yang ditampilkan dalam satu detik ${ }^{7}$.

Media animasi pembelajaran bahasa Arab ini mengangkat tema jam (الستّاعة). Hasil pilihan kosa kata dari tema tersebut meliputi bilangan urut 1-12 dan jam. Kosa kata tersebut sesuai dengan kurikulum dan berhubungan dengan tema السّاعة. Kosa kata yang dimaksud adalah:

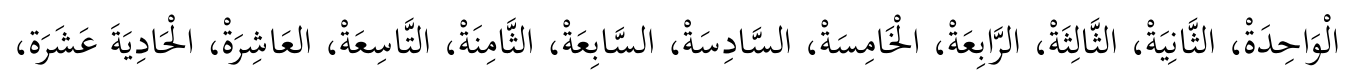

$$
\begin{aligned}
& \text { النَّانيََة عَشَرَة }
\end{aligned}
$$

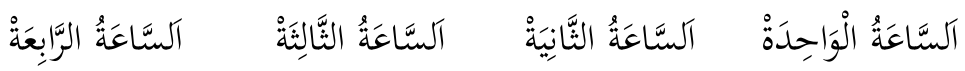

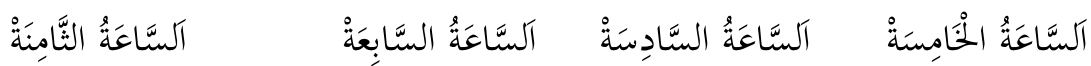

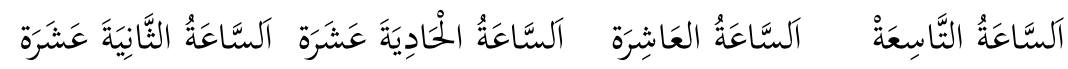

Materi pembelajaran dalam media animasi ini adalah sebagai berikut:

1) Materi istima' dan kalam:

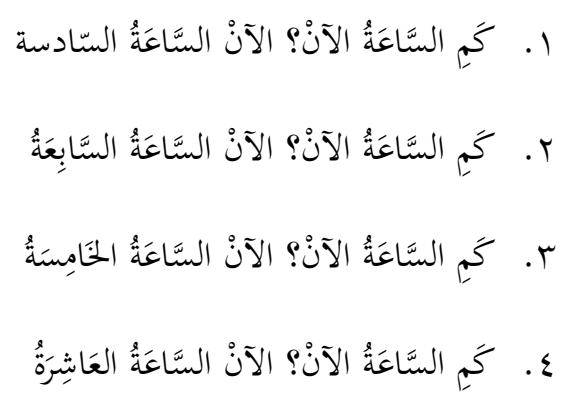

2) Materi qiro'ah

${ }^{7}$ Zeembry. Membuat Animasi Kartu Ucapan dengan Flash 8. (Jakarta: Gramedia. 2007) 


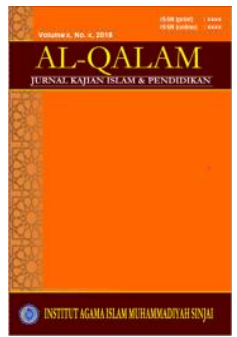

(a) Teks bacaan

$$
\begin{aligned}
& \text { ا. أَذْهَبُ إِلَ الْمَدْرَسَة فِي السَّاعَةِ السَّابِعَةُ }
\end{aligned}
$$

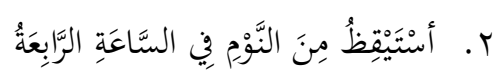

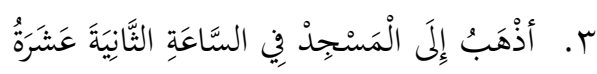

$$
\begin{aligned}
& \text { ع. أَرْجِعُ ٍإلَى الْبَيْتِ فِي السَّاعَة الْوَاحِدَةُ }
\end{aligned}
$$

(b) Pertanyaan tentang isi teks

$$
\begin{aligned}
& \text { 1. فِي أيِّ سَاعَة تَرْجِعُعَاطِمَة إِلَى الْبَيْتِ؟ }
\end{aligned}
$$

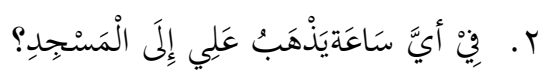

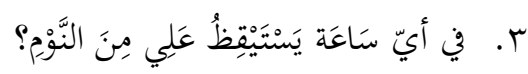

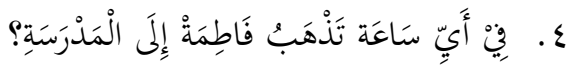

3) Materi kitabah

Urutkan kata-kata dibawah ini menjadi kalimat yang benar:

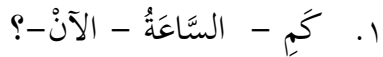

$$
\begin{aligned}
& \text { r. السَّاعَةُ - - السَّابِعَةْ- الآنْ } \\
& \text { r. لِصَلاةِ - الْعِشَاِِ - هَيَّا - نَذْهَبُ }
\end{aligned}
$$

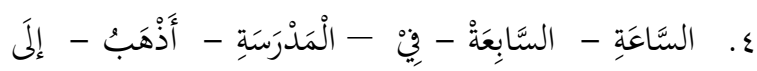

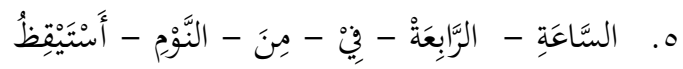

Media animasi ini dikemas dalam film pendek dengan 3 tokoh di dalamnya, yaitu Mirsam, Ali, dan Fatimah. Ali dan Fatimah adalah murid kelas VI MI yang sedang belajar bahasa Arab bersama Mirsam. Mirsam merupakan sebuah pensil ajaib yang membantu ali dan fatimah belajar jam dalam bahasa Arab. Media animasi ini terbagi menjadi beberapa episode pendek. Berikut adalah 


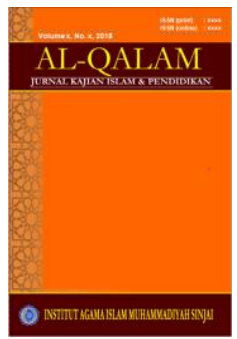

AL-QALAM

Jurnal Kajian Islam \& Pendidikan

Volume 9, No. 1, 2017

ISSN (print) : 1858-4152

ISSN (online) : :xxx-xxxx

Homepage : http://journal.iaimsinjai.ac.id/index.php/al-qalam

isi tiap episode dan tampilan media animasi pembelajaran bahasa Arab kelas VI MI:

\section{Episode Pertama}

Episode pertama merupakan tampilan awal media animasi. Dalam episode pertama ini terdapat logo dan nama universitas, fakultas, jurusan, dan nama peneliti. Setelah itu tokoh animasi memperkenalkan diri.

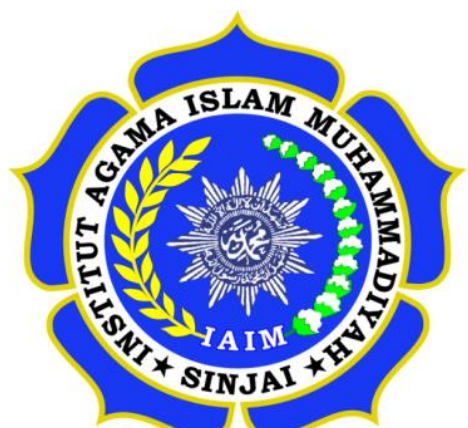

Gambar 1 gambar logo Institut

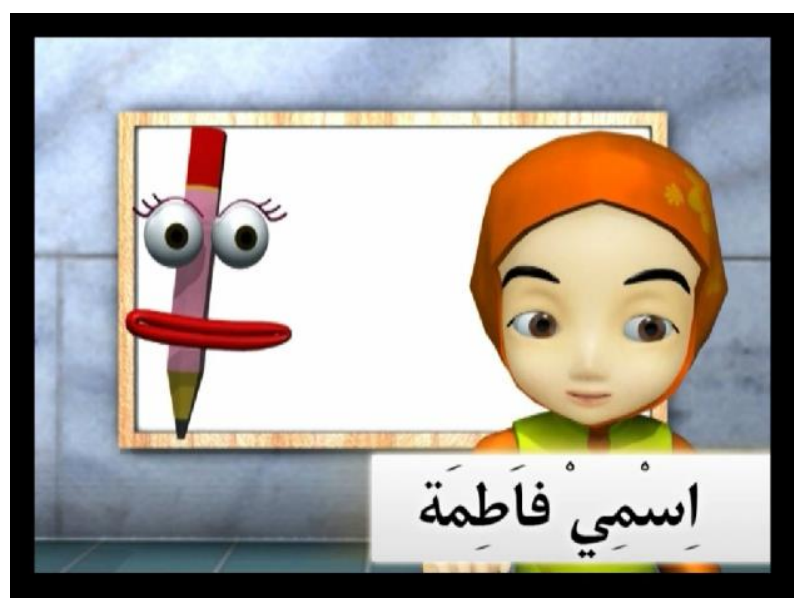

Gambar 2 gambar memperkenalkan diri

Setelah memperkenalkan diri, tokoh animasi mengajak siswa mengingat pelajaran tentang angka 1 sampai 12 dalam bahasa Arab. Hal ini bertujuan untuk mengingatkan siswa pelajaran angka dalam bahasa Arab sehingga akan mempermudah proses pembelajaran tentang jam dalam bahasa Arab. Setelah itu tokoh animasi mengajak siswa untuk belajar menyebutkan jam dalam bahasa 


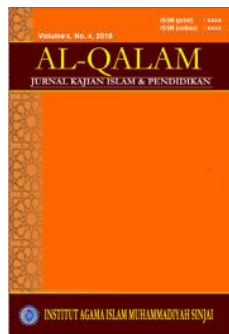

\section{AL-QALAM}

Jurnal Kajian Islam \& Pendidikan

Volume 9, No. 1, 2017

ISSN (print) : 1858-4152

ISSN (online) : xxxx-xxxx

Homepage : http://journal.iaimsinjai.ac.id/index.php/al-qalam

Arab. Pada bagian ini tokoh animasi memberi siswa contoh pengucapan dan penulisan jam dalam bahasa Arab, lalu menyuruh siswa untuk menirukan

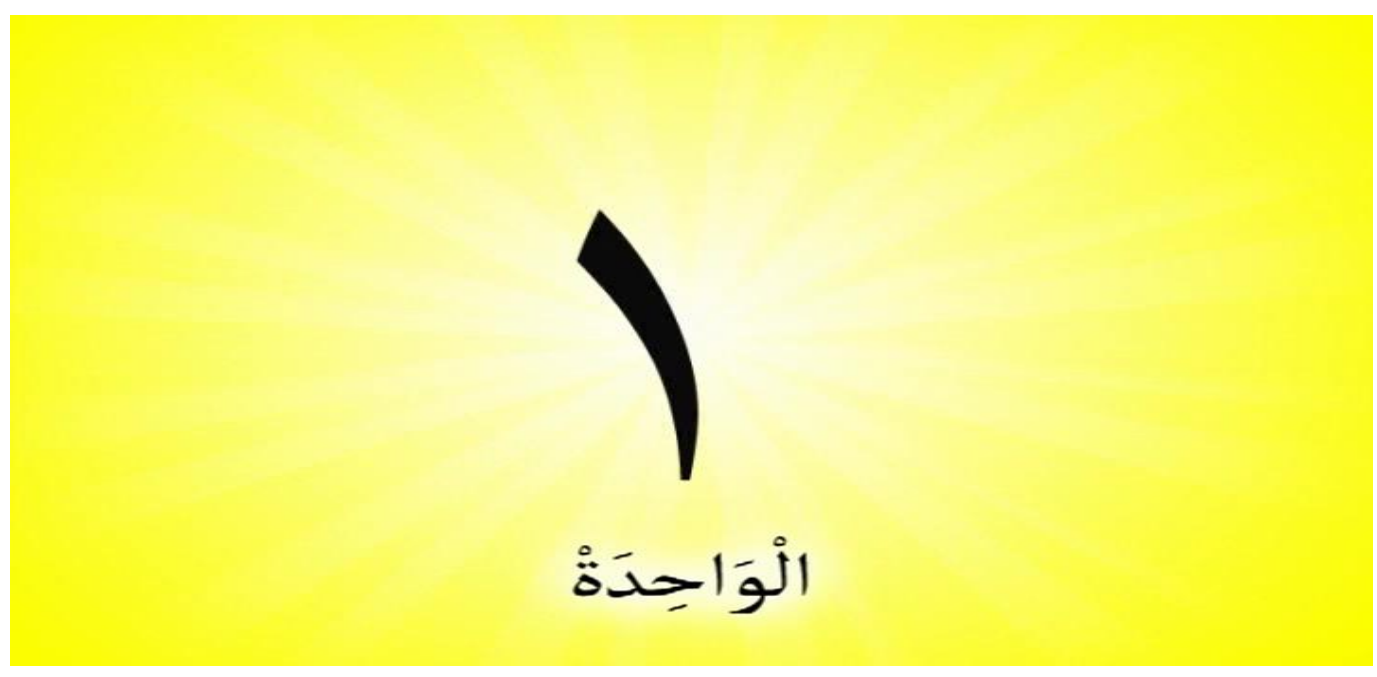

Gambar 4.3 gambar pengulangan materi angka dalam bahasa Arab

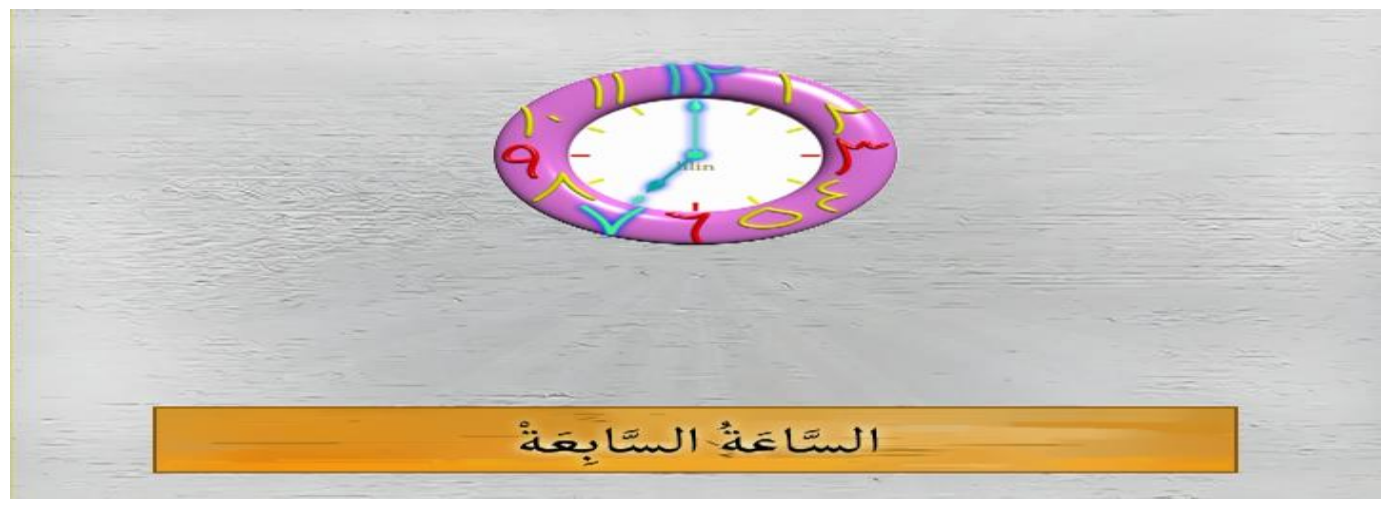

Gambar 4.4 gambar jam disertai pelafalannya dalam bahasa Arab

\section{Episode Kedua}

Pada episode ini, tokoh animasi mengajarkan dua pola kalimat sederhana.

Pola pertama yang diajarkan adalah cara menanyakan jam (كم السّاعة الان؟). Setelah itu tokoh animasi mengajarkan pola kalimat kedua, yaitu cara meyebutkan jam dalam bahasa Arab (الان، السّاعة اليّّاسة). 


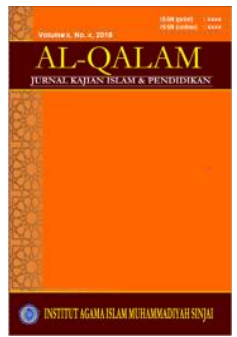

\section{AL-QALAM}

Jurnal Kajian Islam \& Pendidikan

Volume 9, No. 1, 2017

ISSN (print) : 1858-4152

ISSN (online) : xxxx-xxxx

Homepage : http://journal.iaimsinjai.ac.id/index.php/al-qalam

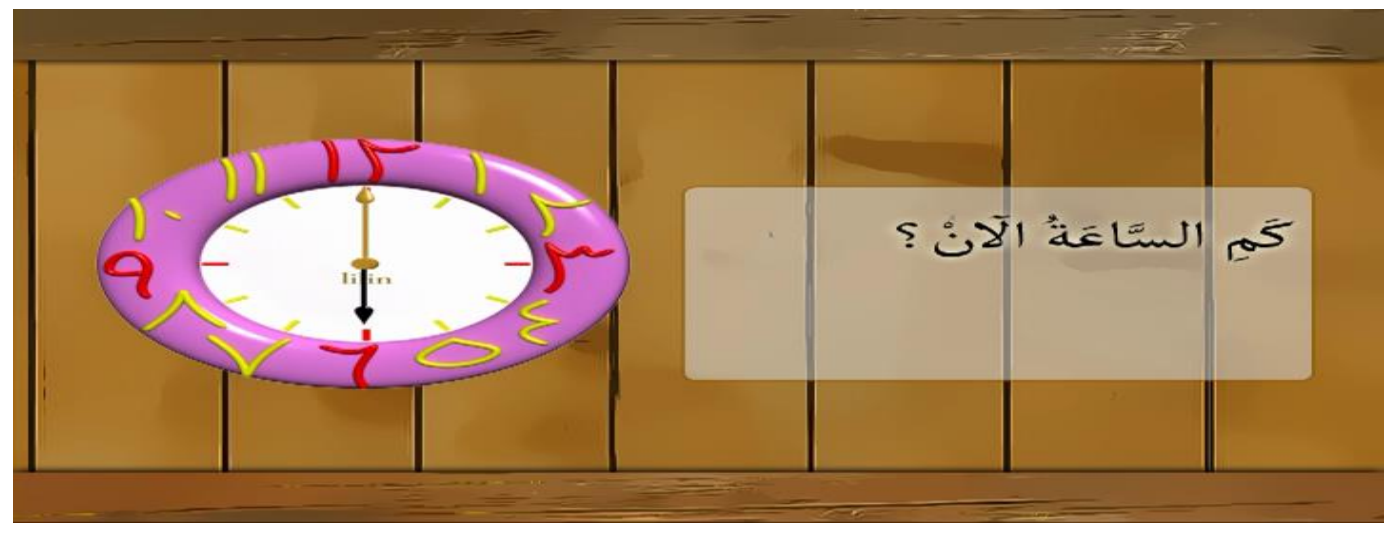

Gambar 4.5 gambar jam disertai kalimat tanya dalam bahasa Arab

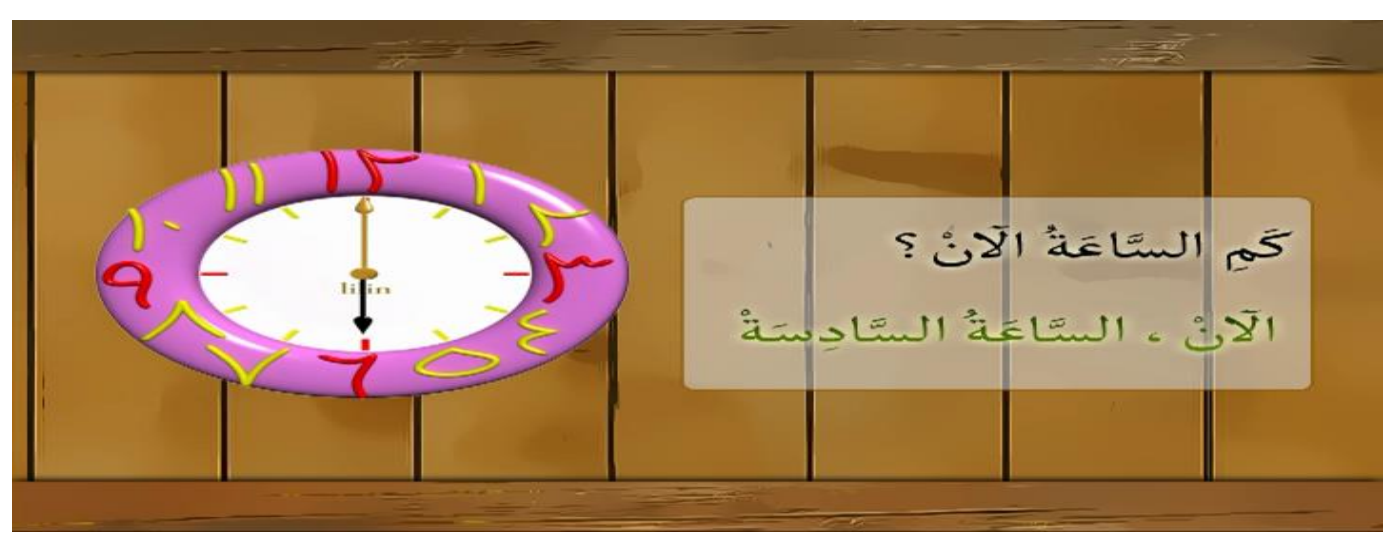

\section{Episode Ketiga}

Gambar 4.6 gambar jam disertai kalimat penjawab

Episode ketiga berisi materi qiro'ah dan latihan kitabah. Materi qiro'ah أذهب إلى ) berupa teks kalimat sederhana seperti yang disampaikan tokoh fatimah (المدرسة في السّاعة السّابعة (akan muncul pertanyaan yang berhubungan dengan kegiatan tokoh animasi

(في أيّ ساعة تذهب فاطمة إلى المدرسة؟), setelah itu akan muncul jawaban dari pertanyaan tersebut (تذهب فاطمة إلى المدرسة في السّاعة السّابعة).

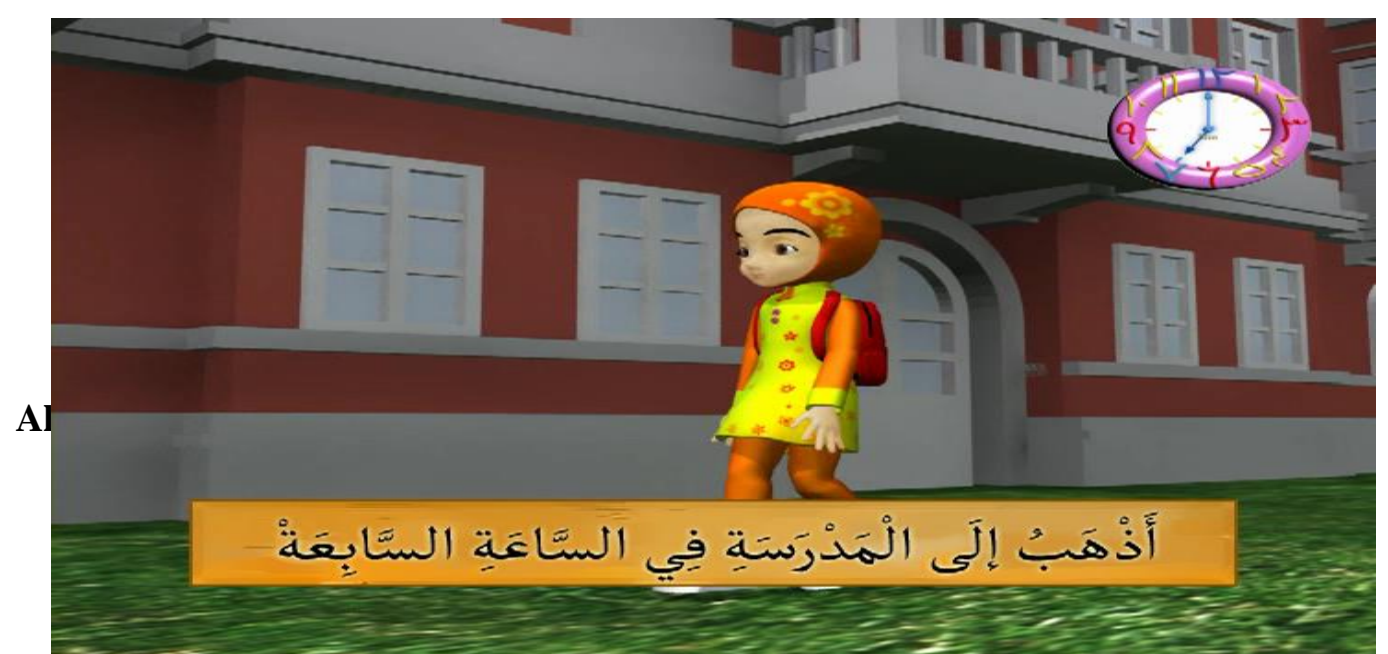




\section{AL-QALAM}

Jurnal Kajian Islam \& Pendidikan

Volume 9, No. 1, 2017

ISSN (print) : 1858-4152

ISSN (online) : xxxx-xxxx

Homepage : http://journal.iaimsinjai.ac.id/index.php/al-qalam

Gambar 4.7 gambar Fatimah ke sekolah disertai dengan contoh menyatakan jam dalam kalimat langsung

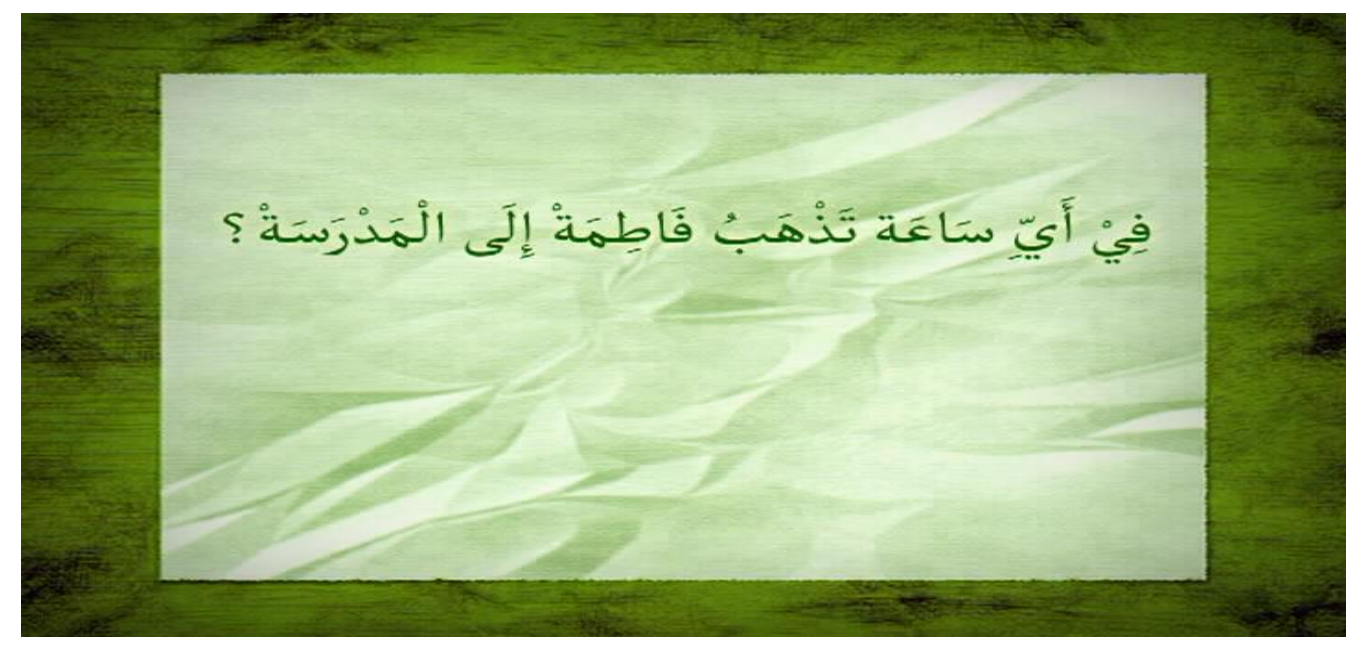

Gambar 4.9 gambar teks pertanyaan

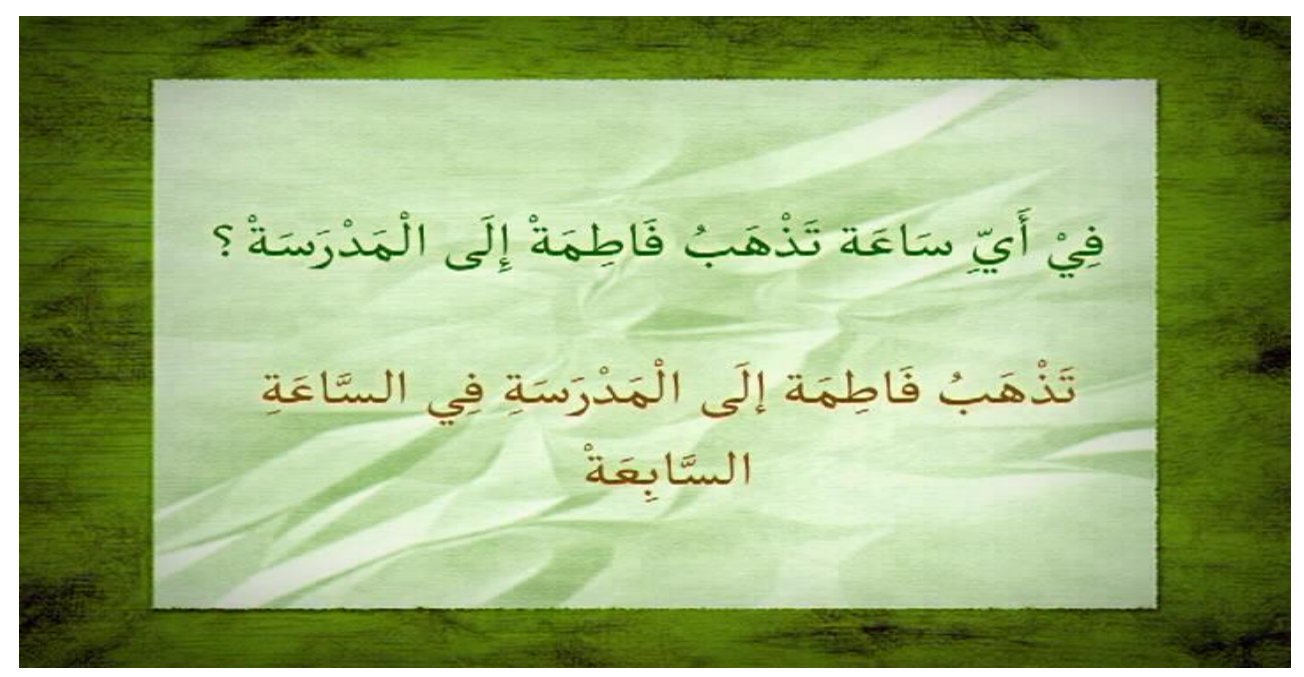

Gambar 4.10 gambar teks pertanyaan dan jawaban pertanyaan 


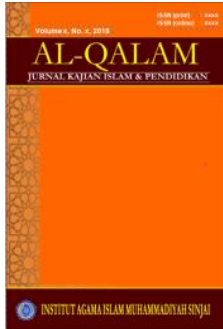

\section{AL-QALAM}

Jurnal Kajian Islam \& Pendidikan

Volume 9, No. 1, 2017

ISSN (print) : 1858-4152

ISSN (online) : $\mathrm{xxxx}-\mathrm{xxxx}$

Homepage : http://journal.iaimsinjai.ac.id/index.php/al-qalam

\section{Episode Keempat}

Episode ini berisi penguatan materi yang sudah disampaikan pada episodeepisode sebelumnya. Materi yang ditampilkan dalam episode ini adalah tanya jawab tentang jam, seperti كَمِ السَّاعَةُ الآنْ؟ الآنْ السَّاعَةُ الثنّانية عشرة، هيّا نذهب لصلاة الظّهر.

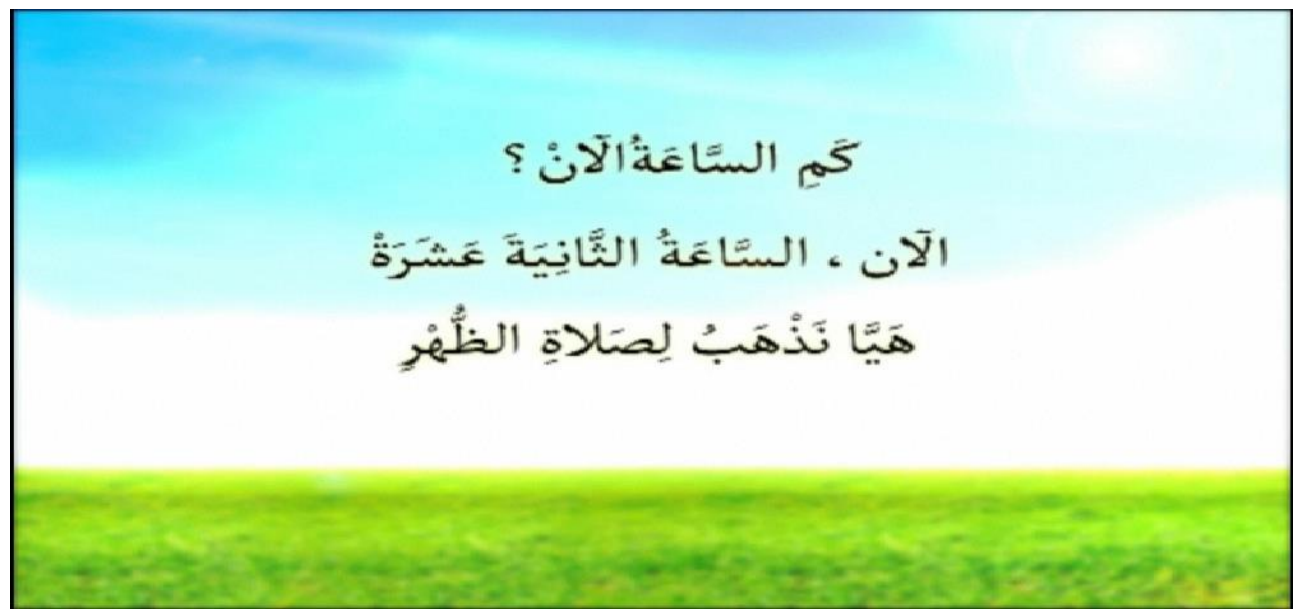

Gambar 4.11 gambar penguatan materi dan penggunaannya dalam kalimat sederhana

\section{Episode kelima}

Episode ini berisi latihan untuk kemahiran menulis yang berbentuk لصلاة_العشاء-هيّا-نذب penyusunan kata-kata acak menjadi sebuah kalimat, seperti هيّا نذهب لصلاة العشاء menjadi

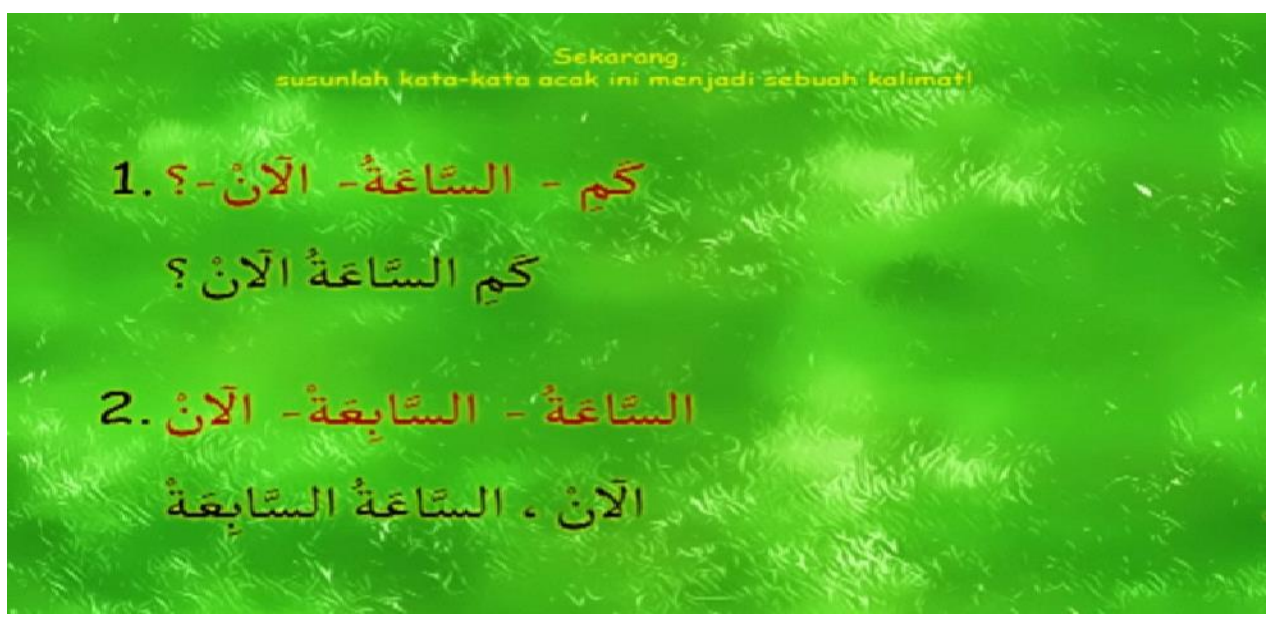

Gambar 4.32 gambar materi kitabah

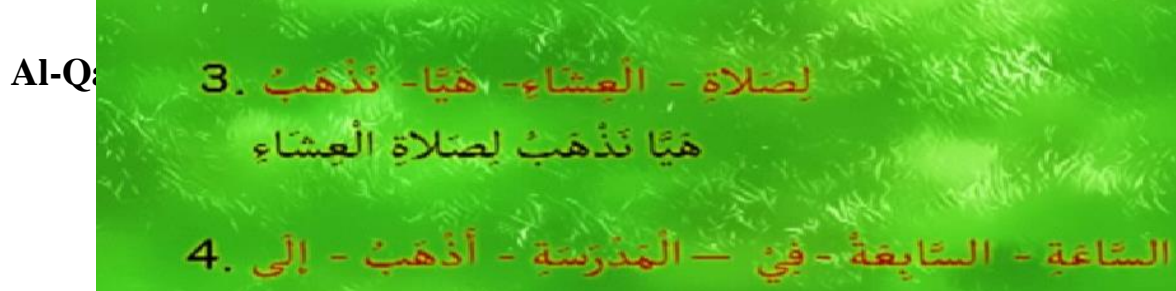




\section{Gambar 4.33 gambar materi kitabah}

\section{B. Kelayakan Produk}

Secara keseluruhan hasil uji coba ahli materi memiliki rata-rata tingkat validitas sebanyak $75 \%$ sehingga media pembelajaran tersebut layak dan harus dilakukan revisi pada aspek-aspek yang mendapatkan nilai dibawah 4 agar didapatkan media yang baik. Aspek-aspek tersebut antara lain; (1) bahasa yang digunakan sederhana dan mudah dipelajari mendapatkan nilai 3 yang berarti cukup valid, (2) kejelasan isi materi mendapatkan nilai 3 yang berarti cukup valid, (3) kejelasan penulisan mufrodat pada media mendapatkan nilai 3 yang berarti cukup valid, (4) kesesuaian pemberian pertanyaan dan tingkat kesulitan soal latihan mendapatkan nilai 3 yang berarti cukup valid, (5) tingkat keefektifan pembelajaran dengan menggunakan media mendapatkan nilai 3 yang berarti cukup valid, (6) ketepatan susunan kalimat mendapatkan nilai 2 yang berarti kurang valid, (7) kesesuaian materi dikaitkan dengan kemahiran mendengar mendapatkan nilai 3 yang berarti cukup valid, (8) kemudahan materi dalam kemahiran mendengar dikaitkan dengan karakteristik siswa mendapatkan nilai 3 yang berarti cukup valid, (9) kesesuaian materi dikaitkan dngan kemahiran membaca mendapatkan nilai 3 yang berarti cukup valid, (10) kemudahan materi dalam kemahiran berbicara dikaitkan dengan karakeristik siswa mendapatkan nilai 3 yang berarti cukup valid, (11) kesesuaian materi dikaitkan dengan kemahiran membaca mendapatkan nilai 3 yang berarti cukup valid, (12) kemudahan materi 


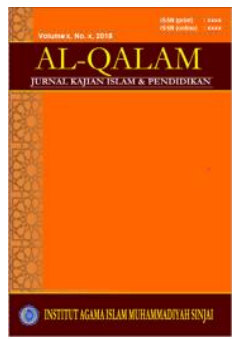

AL-QALAM

Jurmal Kajian Islam \& Pendidikan

Volume 9, No. 1, 2017

ISSN (print) : 1858-4152

ISSN (online) : $\mathrm{xxxx}-\mathrm{xxxx}$

Homepage : http://journal.iaimsinjai.ac.id/index.php/al-qalam

dalam kemahiran membaca dikaitkan dengan karakteristik siswa mendapatkan nilai 3 yang berarti cukup valid, (13) kesesuaian materi dikaitkan dengan kemahiran menulis mendapatkan nilai 3 yang berarti cukup valid, dan (14) kemudahan materi dalam kemahiran menulis dikaitkan dengan karakteristik siswa mendapatkan nilai 3 yang berarti cukup valid.

Secara keseluruhan hasil uji coba ahli media memiliki rata-rata tingkat validitas sebanyak $75 \%$ sehingga media pembelajaran tersebut layak dan harus dilakukan revisi pada aspek-aspek yang mendapatkan nilai dibawah 4 agar didapatkan media yang baik. Aspek-aspek tersebut antara lain; (1) kesesuaian desain media dengan materi pelajaran mendapatkan nilai 3 yang berarti cukup valid, (2) kesesuaian isi media dengan materi pelajaran mendapatkan nilai 3 yang berarti cukup valid, (3) kemenarikan efek animasi dalam media mendapatkan nilai 3 yang berarti cukup valid, (4) kesesuaian antara teks dan suara mendapatkan nilai 3 yang berarti cukup valid, (5) komposisi warna dalam tampilan media mendapatkan nilai 3 yang berarti cukup valid, (6) kejelasan ukuran teks (jenis dan font) mendapatkan nilai 3 yang berarti cukup valid, (7) pengorganisasian dajian media secara berurutan mendapatkan nilai 3 yang berarti cukup valid, (8) keefektifan media yang dikembangkan dalam kegiatan pembelajaran mendapatkan nilai 3 yang berarti cukup valid, (9) kualitas sajian media mendapatkan nilai 3 yang berarti cukup valid, (10) kesesuaian desain media dikaitkan dengan kemahiran mendengar mendapatkan nilai 3 yang berarti cukup valid, (11) keefektifan media diakitkan dengan kemahiran mendengar mendapatkan nilai 3 yang berarti cukup valid, (12) kesesuaian kegiatan berbahasa untuk kemahiran mendengar mendapatkan nilai 3 yang berarti cukup valid, (13) keefektifan media dikaitkan dengan kemahiran berbicara mendapatkan nilai 3 yang berarti cukup valid, (14) kesesuaian desain media dikaitkan dengan kemahiran membaca mendapatkan nilai 3 yang berarti cukup valid, (15) kemudahan latihan mendengar dikaitkan dengan karakteristik siswa mendapatkan nilai 3 yang berarti cukup valid, (16) kesesuaian kegiatan berbahasa untuk kemahiran berbicara 


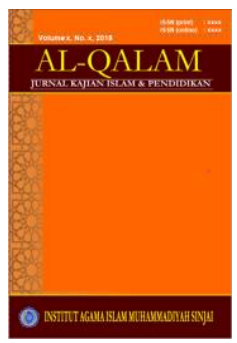

AL-QALAM

Jurnal Kajian Islam \& Pendidikan

Volume 9, No. 1, 2017

ISSN (print) : 1858-4152

ISSN (online) : $\mathrm{xxxx}-\mathrm{xxxx}$

Homepage : http://journal.iaimsinjai.ac.id/index.php/al-qalam

mendapatkan nilai 3 yang berarti cukup valid, (17) kemudahan latihan berbicara dikaitkan dengan karakteristik siswa mendapatkan nilai 3 yang berarti cukup valid, (18) kesesuaian desain media dikaitkan dengan kemahiran membaca mendapatkan nilai 3 yang berarti cukup valid, (19) keefektifan media dikaitkan dengan kemahiran membaca mendapatkan nilai 3 yang berarti cukup valid , (20) kesesuaian kegiatan berbahasa untuk kemahiran membaca mendapatkan nilai 3 yang berarti cukup valid, (21) kemudahan latihan menulis dikaitkan dengan karakteristik siswa mendapatkan nilai 3 yang berarti cukup valid, (22) kesesuaian desain media dikaitkan dengan kemahiran menulis mendapatkan nilai 2 yang berarti kurang valid, (23) keefektifan media dikaitkan dengan kemahiran menulis mendapatkan nilai 2 yang berarti kurang valid, (24) kesesuaian kegiatan berbahasa untuk kemahiran menulis mendapatkan nilai 2 yang berarti kurang valid,dan (25) kemudahan latihan membaca dikaitkan dengan karakteristik siswa mendapatkan nilai 2 yang berarti kurang valid.

Setelah memperoleh data hasil uji ahli materi dan media, maka peneliti melakukan beberapa revisi terkait dengan saran dan masukan dari ahli materi dan media. Dengan adanya revisi baik dari segi materi maupun media, maka diharapkan media animasi untuk pembelajaran bahasa Arab kelas VI MI ini dapat lebih meningkat kualitas dan kevalidan nya, sehingga akan lebih bermanfaat dalam penggunaannya.

Berdasarkan data hasil uji lapangan, maka dapat diketahui bahwa nilai presentase hasil uji lapangan secara keseluruhan adalah 92\%. Hal itu berarti media pengembangan ini valid dan layak digunakan dalam proses pembelajaran. Selain itu media animasi ini juga terbukti efektif digunakan dalam proses pembelajaran karena berdasarkan uji lapangan, setelah menggunakan media pembelajaran ini, hampir semua siswa bisa memahami materi dengan baik.

Media animasi ini dapat digunakan secara mandiri dan berkelompok karena media ini didesain agar bisa digunakan baik secara mandiri maupun berkelompok. Siswa dapat menggunakan media ini secara mandiri di rumah 


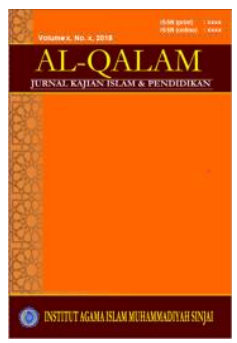

AL-QALAM

Jurnal Kajian Islam \& Pendidikan

Volume 9, No. 1, 2017

ISSN (print) : 1858-4152

ISSN (online) : xxxx-xxxx

Homepage : http://journal.iaimsinjai.ac.id/index.php/al-qalam

setelah siswa mendapat materi tentang jam di sekolah karena media ini dirancang sebagai media penunjang pembelajaran. Tampilan animasi yang lucu dan menarik akan membuat siswa tidak jenuh dan bersemangat dalam menggunakan media ini. Cara penggunaan media secara mandiri adalah dengan memutar CD animasi pembelajaran di computer, laptop, atau VCD. Apabila siswa ingin menjawab pertanyaan dari tokoh animasi, siswa hanya perlu menekan tombol pause lalu menekan tombol play untuk mengetahui jawabannya.

Sedangkan penggunaan media ini secara berkelompok (penggunaan dalam kelas) memerlukan bantuan guru untuk mengontrol tayangan agar pembelajaran menggunakan media ini berjalan efektif. Peran guru dalam penggunaan media animasi ini adalah untuk memberikan penjelasan pada bagian yang memang diperlukan untuk diberi penjelasan dan memberikan penekanan pada bagian yang memang memerlukan penekanan. Untuk itu berikut akan dipaparkan langkahlangkah penggunaan media animasi ini:

\section{a. Penggunaan Episode Pertama}

Pada episode pertama, tokoh animasi memperkenalkan diri dan mengajak siswa untuk mengingat pelajaran tentang angka. Sebelum tokoh animasi menyebutkan angka dalam bahasa arab, guru hendaknya menekan tombol "pause" lalu menanyakan pada siswa apakah mereka masih ingat pelajaran tentang angka, setelah itu guru menyuruh siswa untuk menyebutkan angka 1 sampai 12 dalam bahasa Arab. Setelah siswa menyebutkan angka 1 sampai 12 dalam bahasa Arab, guru menekan tombol "play" dan menyuruh siswa untuk menyebutkan kembali angka 1 sampai 12 dalam bahasa Arab bersama-sama dengan tokoh animasi.

Setelah mengingat pelajaran tentang angka dalam bahasa Arab, tokoh animasi akan mengajak siswa untuk menyebutkan jam dalam bahasa Arab dengan menggunakan pola kalimat sederhana. Sebelumnya, guru bisa menanyakan pada siswa (menggunakan bahasa Indonesia) jam berapa sekarang? Setelah siswa menjawab, guru menanyakan apakah siswa sudah bisa menanyakan dan menyatakan jam dalam bahasa Arab? Setelah itu guru mengajak siswa untuk 


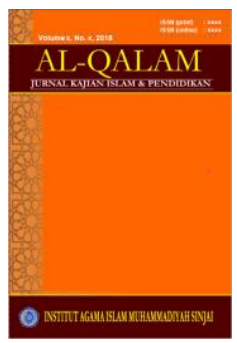

AL-QALAM

Jurmal Kajian Islam \& Pendidikan

Volume 9, No. 1, 2017

ISSN (print) : 1858-4152

ISSN (online) : xxxx-xxxx

Homepage : http://journal.iaimsinjai.ac.id/index.php/al-qalam

belajar menanyakan dan menyatakan jam dalam bahasa Arab dengan menonton video animasi. Akan tetapi sebaiknya guru memberikan penjelasan terlebih dahulu bagaimana menyebutkan jam dalam bahasa Arab menggunakan kalimat sederhana, agar siswa paham dan dapat menyebutkan jam dalam bahasa Arab.

Setelah menjelaskan cara menyebutkan jam dalam bahasa Arab, guru dapat melanjutkan penayangan media animasi. Disaat tokoh animasi menyebutkan jam dalam bahasa Arab, guru menekan tombol "pause" dan menyuruh siswa untuk mengulangi kalimat yang telah disampaikan oleh tokoh animasi secara bergantian dan bersama-sama. Hal ini terus dilakukan sampai episode pertama berakhir.

\section{b. Penggunaan Episode Kedua}

Pada episode kedua, tokoh animasi akan mengajarkan dua pola kalimat sederhana tentang jam. Pola kalimat sederhana yang pertama adalah cara menanyakan jam dalam bahasa Arab. Guru hendaknya memberikan penekanan pada bagian ini dengan menekan tombol "pause" dan menyuruh siswa untuk mengikuti kalimat pertanyaan yang disampaikan tokoh animasi. Sedangkan pola kalimat sederhana yang kedua adalah cara menjawab pertanyaan tentang jam dalam bahasa Arab.

\section{c. Penggunaan Episode Ketiga}

Episode ketiga berisi materi qiro'ah. Penerapannya dapat diwujudkan dengan siswa membaca teks sederhana yang telah disampaikan tokoh animasi terlebih dahulu.

Sedangkan evaluasi qiro'ah dapat diwujudkan dengan siswa menjawab pertanyaan tokoh animasi dengan menulis di papan tulis atau di buku. Pada saat tokoh animasi menanyakan pertanyaan, guru harus menekan tombol "pause" tayangan terlebih dahulu agar siswa tidak mengetahui jawabannya.

Setelah siswa menulis jawaban, guru mengoreksi jawaban siswa dengan menekan tombol "play" sehingga tokoh animasi akan menampilkan jawaban yang benar. 


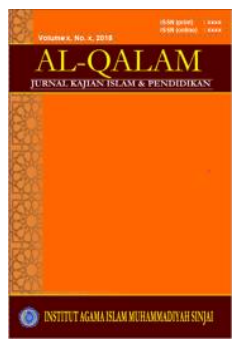

AL-QALAM

Jurmal Kajian Islam \& Pendidilkan

Volume 9, No. 1, 2017

ISSN (print) : 1858-4152

ISSN (online) : xxxx-xxxx

Homepage : http://journal.iaimsinjai.ac.id/index.php/al-qalam

\section{d. Penggunaan Episode Keempat}

Pada episode ke empat, guru dapat memberi penguatan materi pada siswa dengan melakukan evaluasi pembelajaran. Evaluasi pembelajaran dapat dilakukan dengan 2 variasi. Variasi yang pertama adalah disaat tokoh animasi menyampaikan jam dalam bahasa Arab, guru dapat menyuruh siswa menebak atau menulis jam yang telah disebutkan tokoh animasi dengan angka.

Variasi yang kedua adalah guru menekan tombol "pause" setelah tokoh animasi menyebutkan jam dalam bahasa Arab, lalu guru meminta siswa untuk menjawab sholat apa yang dilakukan pada jam yang telah disebutkan tokoh animasi. Setelah siswa menjawab, guru dapat menekan tombol "play" untuk mengoreksi jawaban siswa bersama-sama.

\section{e. Penggunaan Episode Kelima}

Pada episode kelima, tokoh animasi mengajak siswa untuk menyusun katakata acak menjadi kalimat yang benar. Disaat muncul kata-kata acak, guru harus menekan tombol "pause" untuk memberikan siswa waktu berpikir. Setelah itu guru menyuruh siswa untuk menjawab langsung atau menulis jawaban di papan tulis. Setelah siswa menyebutkan atau menulis jawaban, guru mengoreksi jawaban siswa dengan meneka tombol "play" sehingga tokoh animasi akan menampilkan jawaban yang benar.

\section{SIMPULAN DAN SARAN}

Penelitian ini menghasilkan sebuah produk media animasi tentang jam dalam bahasa Arab. Berdasarkan hasil uji ahli, media animasi ini masuk dalam kategori layak dan berdasarkan hasil uji lapangan, media animasi ini masuk dalam kategori sangat layak untuk digunakan dalam proses pembelajaran. Hal itu terlihat dari $96,78 \%$ siswa bersemangat mengikuti pembelajaran dengan menggunakan media ini. Hal itu membuktikan bahwa media animasi mampu meningkatkan motivasi belajar siswa.

Media animasi ini dapat dioprasikan melalui laptop, komputer, dan vcd. Media animasi ini dapat digunakan secara mandiri dan berkelompok. Siswa dapat 


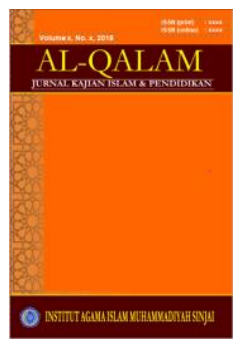

AL-QALAM

Jurnal Kajian Islam \& Pendidikan

Volume 9, No. 1, 2017

ISSN (print) : 1858-4152

ISSN (online) : xxxx-xxxx

Homepage : http://journal.iaimsinjai.ac.id/index.php/al-qalam

menggunakan media ini secara mandiri di rumah setelah siswa mendapat materi tentang jam di sekolah karena media ini dirancang sebagai media penunjang pembelajaran. Tampilan animasi yang lucu dan menarik akan membuat siswa tidak jenuh dan bersemangat dalam menggunakan media ini.

Cara penggunaan media secara mandiri adalah dengan memutar CD animasi pembelajaran di komputer, laptop, atau VCD. Apabila siswa ingin menjawab pertanyaan dari tokoh animasi, siswa hanya perlu menekan tombol pause lalu menekan tombol play untuk mengetahui jawabannya. Sedangkan penggunaan media ini secara berkelompok (penggunaan dalam kelas) memerlukan bantuan guru untuk mengontrol tayangan agar pembelajaran menggunakan media ini berjalan efektif. Pemanfaatan media animasi terutama ketika hal ini merupakan sesuatu yang belum pernah diterima siswa, tentu saja memberikan sebuah pengalaman belajar baru yang lebih menyenangkan dan mampu menarik minat siswa untuk berpartisipasi aktif dalam kegiatan pembelajaran bahasa Arab.

Adapun saran untuk pemanfaatan media adalah sebagai berikut: (1) sebelum menerapkan media ini dalam kegiatan pembelajaran, guru hendaknya terlebih dahulu memberikan pemahaman materi terhadap siswa agar penggunaan media ini berjalan efektif, (2) penggunaan media animasi ini disarankan tidak hanya digunakan di MIN Alehanuae Kab. Sinjai saja, akan tetapi juga digunakan di SD/MI yang lain agar kegiatan pembelajaran bahasa Arab lebih menyenangkan, (3) bagi peneliti atau pengembang lain maupun pengembang selanjutnya yang akan mengembangkan media pembelajaran seperti media ini atau semacamnya diharapkan dapat mengembangkan materi dengan menambah jumlah bab (tema) karena dalam media animasi ini hanya terbatas pada satu bab (tema) saja. Akan lebih baik lagi jika tampilan media animasi dibuat lebih menarik lagi. Selain itu juga diharapkan dapat melakukan uji coba produk pengembangan kepada subjek yang lebih luas dengan kurun waktu yang lebih lama sehingga didapatkan validitas media yang lebih optimal. 


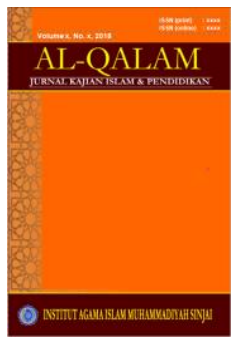

\section{AL-QALAM}

Jurnal Kajian Islam \& Pendidikan

Volume 9, No. 1, 2017

ISSN (print) : 1858-4152

ISSN (online) : :xxx-xxxx

Homepage : http://journal.iaimsinjai.ac.id/index.php/al-qalam

\section{DAFTAR PUSTAKA}

Ainin, Moh. 2010. Metode Penelitian Bahasa Arab. Surabaya. Hilal Pustaka.

Asrori, Imam. 1995. الوسائل الدعينات في تعليم العربيّة. Malang: (tanpa penerbit).

Heriyanto, Albertus, M dan Sandjaja, B. 2006. Panduan Penelitian. Jakarta: Prestasi Pustaka.

Ramli, Kamrianti. 2011. Tanpa judul, (online),

(http://kamriantiramli.wordpress.com/2011/02/28/pengaruh-penggunaanmedia-animasi-sebagai-strategi-pembelajaran-aktif-pada-konsepmetabolisme-di-kelas-xii-man-negeri-2-sinjai/)diakses 13 Desember 2017.

Suaidah, Nisful Laily. 2011. Pengembangan Media Pembelajaran Berbasis Adobe Flash CS3 dalam Kemahiran Kalam untuk Siswa Kelas VII SMP Darul Qur'an Singosari Malang. Skripsi tidak diterbitkan. Malang: Fakultas Sastra Universitas Negeri Malang.

Zeembry. 2007. Membuat Animasi Kartu Ucapan dengan Flash 8. Jakarta: Gramedia. 